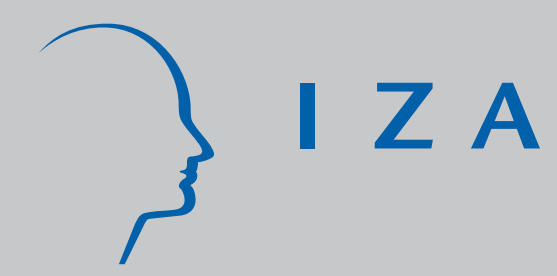

IZA DP No. 309

On the Complementarity between Education and Training in Europe

Giorgio Brunello

J une 2001 


\title{
On the Complementarity between Education and Training in Europe
}

\author{
Giorgio Brunello \\ University of Padova, CESifo, FEEM and IZA, Bonn
}

\author{
Discussion Paper No. 309 \\ June 2001
}

\author{
IZA \\ P.O. Box 7240 \\ D-53072 Bonn \\ Germany \\ Tel.: +49-228-3894-0 \\ Fax: +49-228-3894-210 \\ Email: iza@iza.org
}

This Discussion Paper is issued within the framework of IZA's research area The Future of Work. Any opinions expressed here are those of the author(s) and not those of the institute. Research disseminated by IZA may include views on policy, but the institute itself takes no institutional policy positions.

The Institute for the Study of Labor (IZA) in Bonn is a local and virtual international research center and a place of communication between science, politics and business. IZA is an independent, nonprofit limited liability company (Gesellschaft mit beschränkter Haftung) supported by the Deutsche Post AG. The center is associated with the University of Bonn and offers a stimulating research environment through its research networks, research support, and visitors and doctoral programs. IZA engages in (i) original and internationally competitive research in all fields of labor economics, (ii) development of policy concepts, and (iii) dissemination of research results and concepts to the interested public. The current research program deals with (1) mobility and flexibility of labor markets, (2) internationalization of labor markets and European integration, (3) the welfare state and labor markets, (4) labor markets in transition, (5) the future of work, (6) project evaluation and (7) general labor economics.

IZA Discussion Papers often represent preliminary work and are circulated to encourage discussion. Citation of such a paper should account for its provisional character. 
IZA Discussion Paper No. 309

June 2001

\title{
ABSTRACT \\ On the Complementarity between Education and Training in Europe*
}

This paper is an empirical investigation of the complementarity between education and training in 13 European countries, based on the European Community Household Panel (ECHP). After confirming the standard result that training incidence is higher among individuals with more education, I find that the relationship between educational attainment and training incidence varies significantly across countries and birth cohorts. I show that individuals have a higher training incidence in countries with a more educated labor force, a less stratified schooling system, a higher union density and a lower value of the Kaitz index. I also find evidence that individuals with more education and limited labor market experience enjoy higher private returns from recent training than individuals with the same experience and less education. More experienced individuals with higher education, however, have lower returns from recent training than less educated workers with the same experience.

JEL Classification: J24, J31

Keywords: Education, training, Europe

\author{
Giorgio Brunello \\ Department of Economics \\ University of Padova \\ Via del Santo 33 \\ I - 35100 Padua \\ Tel.: +39 (0) $49827-4223$ \\ Fax : +39 (0) $49827-4211 / 4221$ \\ Email: brunello@vi.nettuno.it
}

\footnotetext{
* This research was supported by the European Commission under the TSER program PL980182 for the PuRE project. The usaual disclaimer applies.
} 


\section{Introduction}

There is a large empirical literature that investigates the incidence of training and its economic returns. Most of this literature is based on national data and comparative work to assess training incidence and the relative size of the returns to training in different countries is scarce (Pischke [2000]). One important empirical topic in this literature is whether training and education are complements or substitutes. Quoting from Heckman [1999] "..human capital has fundamental dynamic complementarity features. Learning begets learning. Skills acquired early on make later learning easier" (p.6).

Three questions are relevant here: a) does the incidence of training increase among the more educated; b) does a higher supply of educated workers in a country favor the incidence of training, because of the presence of externalities; c) are the private returns to training higher among the more educated? When training matters for earnings and for economic growth, and both the incidence and the returns to training increase among the more educated, more education becomes an important policy priority.

In this paper, I try to answer these questions by using a large dataset, the European Community Household Panel (ECHP), that covers 14 European countries and includes questions about education and training. The ECHP data have two advantages: the first is comparability; the second is that it covers a large number of European countries, that have different educational systems and labor market institutions. Therefore, I can study whether these differences affect training ${ }^{1}$.

This empirical paper is organized as follows. Section 2 spells out the empirical implications of the relationship between education and training. Section 3 illustrates the data. Sections 4 and 5 are devoted to the empirical evidence on training incidence and on the private returns to training. Conclusions follow.

\footnotetext{
${ }^{1}$ As recently discussed by Acemoglu and Pischke [1999], labor market imperfections, such as for example the minimum wage and the active presence of unions, can alter in a significant way the standard beckerian framework and its implications for the private incentives to invest in training and for training incidence.
} 


\section{Education and Training}

The idea that education and training are complements goes back at least to Rosen [1976], who argued in his theory of lifetime earnings that education improves job related learning skills, thereby reducing training costs. According to this view, individuals with more education should receive, ceteris paribus, more training.

When the human capital accumulated at school facilitates training, both on the job and off the job, I expect older individuals to have a lower training incidence than younger workers with the same educational attainment, because their education is more outdated (see Neuman and Weiss [1995]). The empirical implication is that the complementarity between education and training should be lower for individuals belonging to older birth cohorts.

It is natural to expect that not only the quantity but also the quality of education matters for the relationship between education and training. The organization of schools in Europe differs markedly. Broadly speaking, I can classify national systems according to the degree of differentiation of secondary schools between vocational and general tracks. While in some countries, most notably Germany, tracking into vocational and general streams starts early, at about 10 years of age, in other countries, such as Ireland or the UK after the reform of the mid 1960s, secondary schools are comprehensive and differentiation starts later. If comprehensive systems reduce specialization in favor of flexibility, as suggested by Shavit and Muller [1998] and Brunello and Giannini [2000], the empirical implication is that these systems require, for a given level of education, more training that stratified systems.

Government training policies are often justified by the presence of externalities. As discussed by Acemoglu [2000], Soskice [1994], Snower [1994] and Brunello and Medio [2001], a training supply externality occurs when an increase in the supply of educated workers raises the probability that firms fill successfully their training vacancies for skilled jobs, and thereby raises the expected return from opening these vacancies. In these circumstances, training incidence increases not only with individual educational attainment but also with the share of educated 
individuals in the labor force.

Education and training can be complements in the production of human capital, that affects earnings capacity. Following Willis [1986], assume that $\log$ earnings $\ln W$ be proportional to earnings capacity $H$, and let earnings capacity depends on education and training. Then I have

$$
\ln W=g[H(E, T)]
$$

where $g$ is an increasing function of $H, E$ is educational attainment (years of schooling) and $T$ is training. Complementarity between $E$ and $T$ in the production of earnings capacity implies that

$$
\frac{\partial \ln W}{\partial T \partial E}>0
$$

so that individuals with more education have more to gain from investing in training.

The standard economic theory of training was developed by Becker by assuming competitive labor markets. When labor markets are non - competitive, however, labor market institutions that affect wage compression can affect training incidence. Acemoglu and Pischke [1998] show that a more compressed wage structure, induced either by a minimum wage or by the presence of unions, is likely to increase the provision of general training when firms bear the training cost. When both firms and workers contribute to training investments, however, wage compression may increase or decrease the total provision of training. The sign of this relationship is an empirical matter.

\section{The Data}

The data used in this paper are drawn from the 1994 and 1996 waves of the European Community Household Panel, a household survey that covers 14 European countries ${ }^{2}$. The main advantage of these data is that the same "community" questionnaire is adopted by the national data collection units in each participating country, which obviously increases comparability. Each wave includes a household and a personal

\footnotetext{
${ }^{2}$ The countries are: Germany, Denmark, Netherlands, Belgium, France, UK, Ireland, Italy, Luxembourg, Greece, Spain, Portugal, Austria and Finland. We exclude Luxembourg from this study because of its small size.
} 
file, and the same households and individuals are interviewed over time. In the 1994 wave, 60500 nationally representative households and approximately 130000 individuals from 12 countries were interviewed. In the 1996 wave Austria and Finland joined the project ${ }^{3}$.

I consider in this paper only individuals aged between 16 and 60 who at the time of the survey have completed schooling and are working in paid employment more than 15 and less than 60 hours per week $^{4}$. The key question about training in the survey asks whether the interviewed person has been in education or training since January of the year before the year of the interview. The reference period is 1993-94 for the first wave, 1994-95 for the second wave and 1995-96 for the third wave. Since the reference period of the second wave overlaps with the other two waves, I use only the first and last wave of the longitudinal data. No information is available on training experiences before 1993.

Individuals in paid employment at the time of the survey who have been in education or training during the reference period are asked what kind of course they have been on. The alternatives include general education, vocational or training courses and language courses. I define the dummy variable $T$ as equal to 1 when the individual has been in a vocational or training course, and equal to 0 otherwise.

The survey then asks individuals with $T=1$ the type of vocational or training course received, and distinguishes among third level qualification, such as technical college $(9.4 \%$ of those investing in training in 1995-96), specific vocational training at a vocational school or college $(34.1 \%)$, vocational training in a dual system (14.9\%), training in a working environment $(39.1 \%)$ and else $(2.5 \%)$. In some countries, most notably the UK, Finland, Denmark and Belgium, the response rate to this question is significantly below the percentage of trained individuals. For this reason, I prefer not to use in this paper the potentially useful distinction between general and firm specific training. It follows that my definition of training includes both types of investment.

\footnotetext{
${ }^{3}$ See European Commission [1999].

${ }^{4}$ I exclude individuals whose main activity status at the time of the survey is paid employment for less than 15 hours per week, paid apprenticeship, training or education, self-employment, unpaid family worker, out of the labor force and unemployed.
} 
The ECHP survey asks individuals about the highest level of general education completed, and codes the answers into three categories: less than second stage level or lower secondary education ( $E_{1}$ : ISCED 0-2), second stage level or upper secondary education ( $E_{2}:$ ISCED3); recognized third level education ( $E_{3}$ : ISCED $\left.5-7\right)$. Table 1 shows by country and gender the percentage of individuals interviewed in 1996 who received training during the reference period (1995-6) and the distribution of individuals by highest education attainment.

The percentage of people investing in training during the reference period is highest in Finland, Denmark and the UK and lowest in Greece, Italy and Portugal. In some countries, the percentage of trained individuals is higher among females than among males. Upon inspection, there is no clear pattern relating the percentage of trained individuals with the share of individuals with higher education. Denmark has almost a twice as high proportion of trained individuals as Belgium, but about the same proportion of college graduates; Greece has a very low proportion of trained individuals, despite having a composition of educational attainment rather similar to the UK, where the proportion of trained individuals is much higher.

\section{Training Incidence}

I start my empirical investigation by estimating a probit model for the incidence of training in 1996

$$
\operatorname{Pr} o b[T=1]=\Phi\left(Z^{\prime} \beta\right)
$$

where $Z$ is a set of explanatory variables, $\beta$ is a vector of parameters, and $\Phi$ is the standard normal distribution. In the baseline regression, I include among the explanatory variables: a gender dummy (Gender), equal to 1 for males and to 0 for females; two education dummies, one for attained tertiary education $\left(E_{3}\right)$ and the other for attained upper secondary education $\left(E_{2}\right)$; age $(A g e)$; experience, measured as age minus age at labor market entry $(X)$; marital status (Married); days of absence from work during the month before the interview due to illness or other reasons (Absence); health conditions (Health $=1$ if conditions are good 
or fair, 0 otherwise); average hours worked per week (Hours); sector of employment (Private $=1$ if employed in the private sector, 0 otherwise); unemployment during the 5 years before the survey (Unemp5) and a dummy equal to 1 when the individual has experienced during the 5 years before the survey at least one unemployment spell longer than one year $(U l)$.

The summary statistics of these variables are shown in Table 2. It turns out that close to $20 \%$ of the individuals in the sample have invested in training during the period $1995-96^{5}$. Average age and average experience are close to 38 and 19 years respectively. Close to $60 \%$ of the sample is composed of males and about $66 \%$ of the sampled individuals are employed in the private sector. While only about $2.5 \%$ of the individuals in the sample are in poor health, more than $20 \%$ have experienced unemployment in the five years before the survey, and $8 \%$ have been in at least one unemployment spell lasting more than 1 year.

Table 3 presents my results on training incidence. The coefficients in the table are marginal effects, that measure the change in the probability of training for an infinitesimal change in each independent, continuous variable and the discrete change in the probability for dummy variables. I find that training incidence is higher among younger individuals who are single, healthy, and have not experienced unemployment during the 5 years before the survey, and lower among individuals who have accumulated more days of absence, have worked shorter hours and are employed in the private sector.

I also find that, ceteris paribus, individuals with college education $\left(E_{3}=1\right)$ have the highest probability of investing in training. Individuals with upper secondary education $\left(E_{2}=1\right)$ do better than individuals with lower education but not as well as college graduates. The increase in the probability of training associated to an upper secondary and to a college degree is 0.056 and 0.085 respectively. This result is expected and confirms the broad view that the incidence of training is higher among

\footnotetext{
${ }^{5}$ The percentage investing in training varies with educational attainment and is equal to 0.099 among individuals with less than upper secondary education, to 0.220 among individuals with upper secondary education and to 0.346 among college graduates.
} 
the more educated.

The relationship between educational attainment and training incidence varies significantly across countries, as documented in columns (3) and (4) of the table, where I present the results of a regression that includes interactions between each educational dummy and country dummies. For ease of interpretation, I only report the significant interactions. The Netherlands is the only country in the sample where higher education reduces the incidence of training. To the other extreme, Ireland is the country where more education increases training incidence the most. In a number of countries (the UK, Spain and Finland) the incidence of training is highest among individuals with at most upper secondary education.

The uncovered cross - country differences in the relationship between education and training incidence could depend, at least in part, on the way schools are organized in European countries. One important dimension of school design is the degree of differentiation between vocational and academic or general tracks. In some countries (for instance Germany), differentiation is high and starts early on. In other countries, secondary schools are comprehensive and there is little differentiation between tracks (for instance Ireland). School design in the remaining countries falls between these two extremes (Shavit and Muller [1998]).

I consider whether school design matters in the last two columns of the table, where I show the results of interacting each educational dummy with the dummy Tracking, that is equal to 3 for the countries where secondary schools are very stratified (Germany and Austria), to 2 for countries where stratification is important (the Netherlands and Belgium), to 1 where there is some degree of stratification (France, Italy, Spain and Portugal) and to 0 where schools are comprehensive (UK, Ireland, Denmark and Finland $)^{6}$. My results suggest that the impact of educational attainment on the incidence of training is significantly lower in more stratified schooling systems. This appears to be consistent with

\footnotetext{
${ }^{6}$ I have assigned values to countries depending on the school age when differentiation begins. See OECD [1992], Hannan, Raffe and Smyth [1996] and Lassibille and Navarro Gomez [1998] for details on school design in Europe.
} 
the view that stratified schools increase specialization, thereby reducing the need to undertake additional training after labor market entry ${ }^{7}$.

The ECHP dataset also includes a question on the overall duration of training. Based on this question I define the variable $D$ (duration), that takes the value 1 when training lasts less than 2 weeks, 2 when training lasts between 2 and 9 weeks, and 3 for longer training spells. Table 4 presents the results of an ordered probit that associates the duration of training to the same explanatory variables used in the first two columns of Table 3. The main result is that educational attainment does not affect significantly the duration of training. Duration is higher among females, younger and single workers, in the private sector and among individuals who have worked fewer hours and have been unemployed during the 5 years before the survey.

I study whether the uncovered complementarity between educational attainment and training incidence varies with the cohort of birth by replacing individual age with cohort dummies and by including in the regression the interactions between these dummies and the two educational dummies. Table 5 presents the results. When I consider individuals with at most lower secondary education, the evidence suggests that older individuals receive less training. When I turn to individuals with upper secondary or tertiary education, however, the evidence shows the contrary, and older educated individuals invest more, not less, in training than younger workers with the same educational attainment.

I can think of at least two alternative explanations of these findings. First, training is more frequent among more educated older workers because the vintage of their human capital has depreciated faster than the human capital of younger workers with the same education. As argued by Neuman and Weiss [1995]

"..it is reasonable to assume that an elementary school graduate's human capital does not suffer much from obsolescence since the material taught in

\footnotetext{
${ }^{7} \mathrm{~A}$ possible objection is that school design has changed over time in some countries. Italy and the UK are examples of shifts from a stratified to a more comprehensive system, that occurred in the mid sixties. My qualitative findings are robust, however, to excluding from the sample the individuals born before 1955, who went to junior high school before these reforms took place.
} 
elementary schools has not changed much over time. However, an electrical engineer who was trained 20 years ago learned vastly different material than one who just finished his schooling.." (p.946).

In such circumstances, training operates as a substitute for outdated education. Alternatively, recall that I only consider the training that occurs since the year before the survey. If training before this interval and recent training are complements, so that learning begets learning, older educated workers have a higher training incidence because they have received more training in the past.

In the presence of a training supply externality, I expect the incidence of training in each country to increase with the aggregate supply of educated workers, that I measure with the percentage of individuals who have attained at least upper secondary education in $1992^{8}$. I also expect training incidence to vary with labor market institutions, because wage compression affects the incentives to invest in training in noncompetitive labor markets.

The country differences in labor market institutions are illustrated in Table 6. I exclude Greece from this and the next table, because of lack of data. My indicators of labor market institutions include the OECD index of employment protection $(E p l)$, that increases with the degree of protection and is highest in Italy (14.25) and lowest in the UK (2.25); average union density (Udens) during the period 1975-95, that ranges from $14 \%$ in France and Spain to $73 \%$ in Denmark; and the Kaitz index (Minw), the ratio between the minimum wage and the average wage, that is lowest in Spain (0.32) and highest in Italy (0.71).

By increasing turnover costs and discouraging involuntary separations, higher employment protection is expected to favor the investment in human capital. In an imperfect labor market, stronger unions increase wage compression, reduce turnover and encourage firms to sponsor general training programs (Acemoglu and Pishke [1999]; Booth, Francesconi and Zoega [1999]). Similarly, a high minimum wage relative to the average wage also increases wage compression and favors firm - sponsored general training. As stressed by Acemoglu and Pischke [1998], how-

\footnotetext{
${ }^{8}$ Source: OECD [1995].
} 
ever, "..non - competitive theories do not predict that wage compression should necessarily increase training, but that this is a possibility..." (p.16).

Table 6 also includes the dummy Tracking introduced above and $E d 2$, the share of active population with at least upper secondary education in 1992. Educational attainment is highest in Germany, Austria and the UK and lowest in Italy, Spain and Portugal. Table 7 presents my estimates of the incidence of training when the country dummies are replaced by a vector of institutional variables, that include Epl, Udens, Tracking, Ed92 and the Kaitz index ${ }^{9}$. These variables vary across countries but are constant among individuals belonging to the same country. Therefore, I adjust the standard errors by allowing errors to be independent among countries and dependent within countries. My findings are summarized as follows:

- the incidence of training is higher in countries with a higher supply of educated labor, suggesting the presence of a positive training supply externality;

- training is more frequent in countries where union density is higher;

- training is less frequent in countries with a higher minimum wage;

- training incidence is lower in countries with more stratified secondary schools;

- training incidence is higher in countries with a higher index of employment protection.

The first and the last two results are in line with my expectations. Since both a higher union density and a higher minimum wage lead to more wage compression, the indirect evidence on the relationship between wage compression and training incidence is not clear-cut. My

\footnotetext{
${ }^{9}$ An alternative to replacing country dummies with institutional variables is to use a two step method: in the first step one estimates country dummies; in the second step weighted least squares are used to regress these dummies on institutional variables. See Card and Krueger [1990].
} 
results suggest that countries with relatively high union density and low minimum wages (Finland and Denmark) have a higher training incidence than countries with relatively low union density and high minimum wages (Italy and Austria).

\section{$5 \quad$ Training and Earnings Growth}

In this section I use the longitudinal nature of the ECHP dataset to study the relationship between education, training and earnings growth. Let the relationship between earnings and training and education in 1994 be characterized by the following Mincerian function

$$
\begin{gathered}
\ln W_{94 i}=f_{i}+Y_{i}^{\prime} \alpha_{94}+\beta_{94} T_{94 i}+\rho_{94 i} X_{i}+v_{94 i} X_{i}^{2}+\sum_{h} \gamma_{94 h} E_{h i} \\
\text { +interactions }\left[T_{94 i},\left(E_{h i}, X_{i}, X_{i}^{2}, E_{h i} X_{i}, E_{h i} X_{i}^{2}\right)\right]+\epsilon_{94 i}
\end{gathered}
$$

where $h=2,3, i$ is the subscript for the individual, $W_{94}$ is hourly net earnings in $1994^{10}, Y$ is a vector of occupational and sectorial dummies, $T_{94}$ is the dummy for training during 1993-94 (previous training), $X$ is labor market experience in 1994 and I include the interactions among training and the variables in parentheses. The error term is composed of two parts, a time invariant individual effect $f_{i}$ and a time specific effect, $\epsilon_{94 i}$. A similar relationship characterizes earnings in 1996

$$
\begin{gathered}
\ln W_{96 i}=f_{i}+Y_{i}^{\prime} \alpha_{96}+\sigma_{96} T_{96 i}+\beta_{96} T_{94 i}+\rho_{96 i} X_{i}+v_{96 i} X_{i}^{2} \\
+\sum_{h} \gamma_{96 h} E_{h i}+\text { interactions }\left[T_{94 i},\left(E_{h i}, X_{i}, X_{i}^{2}, E_{h i} X_{i}, E_{h i} X_{i}^{2}\right)\right] \\
\quad+\text { interactions }\left[T_{96 i},\left(E_{h i}, X_{i}, X_{i}^{2}, E_{h i} X_{i}, E_{h i} X_{i}^{2}\right)\right]+\epsilon_{96 i}
\end{gathered}
$$

where $W_{96}$ are hourly earnings in 1996, $T_{96}$ is the dummy for training during 1995-96 (current training), and I explicitly allow for the possibility that previous training experience affects current earnings, both directly and via interactions with education and experience ${ }^{11}$.

\footnotetext{
${ }^{10}$ With the exception of France, where earnings are gross of taxes.

${ }^{11}$ In (5) I use the fact that experience in 1996 is equal to experience in 1994 plus 2 and I consider only individuals who have the same educational attainment in 1994 and 1996.
} 
The individual fixed effect includes unobserved characteristics, such as ability, and is clearly correlated with the participation of individuals in training programs. For this reason, I follow Lynch [1992], Blundell, Dearden and Meghir [1994] and Arulampalam, Booth and Elias [1997] among others, and use the data from the two waves, 1994 and 1996, to eliminate the time invariant individual fixed effect $f_{i}$ by taking first differences over time ${ }^{12}$. Recalling that my longitudinal sample includes only individuals employed both in 1994 and in 1996, I get

$$
\begin{aligned}
& \Delta \ln W_{96 i}=Y_{i}^{\prime}\left[\alpha_{96}-\alpha_{94}\right]+\sigma_{96} T_{96 i}+\left[\beta_{96}-\beta_{94}\right] T_{94 i}+\sum_{h}\left[\gamma_{96 h}-\gamma_{94 h}\right] E_{h i} \\
& +\left[\rho_{96}-\rho_{94}\right] X_{i}+\left[v_{96}-v_{94}\right] X_{i}^{2}+\text { interactions }\left[T_{94 i},\left(E_{h i}, X_{i}, X_{i}^{2}, E_{h i} X_{i}, E_{h i} X_{i}^{2}\right)\right] \\
& \quad+\text { interactions }\left[T_{96 i},\left(E_{h i}, X_{i}, X_{i}^{2}, E_{h i} X_{i}, E_{h i} X_{i}^{2}\right)\right]+\epsilon_{96 i}-\epsilon_{94 i}
\end{aligned}
$$

Notice that the interactions between previous training and education appear in the earnings growth equation only if their effects on earnings in 1994 and 1996 vary. On the other hand, the parameters associated to the interactions between current training and education reflect the joint impact of these variables on earnings in 1996. When the economic returns to current training are not independent of educational attainment, at least some of the interactions involving current training and education in (6) should be significantly different from zero.

While the time invariant fixed effect has been removed by differentiation over time, I cannot rule out the possibility that participation in current training be correlated with the temporary shock $\epsilon_{96 i}-\epsilon_{94 i}{ }^{13}$. I deal with this possibility in two ways. First, I introduce country specific dummies, that capture the effects of country specific aggregate shocks. Second, I follow Blundell, Dearden and Meghir [1994] and add to the empirical model in (6) the inverse Mills ratio $\lambda_{T 96}$. This ratio is estimated by fitting a probit for current training and by using as regressors

\footnotetext{
${ }^{12} \mathrm{By}$ so doing I are forced to eliminate from the sample the data for Austria and Finland, that are available only for 1996. Since I only consider individuals who have finished school, schooling is time invariant.

${ }^{13}$ This possibility can be safely excluded for previous training, that occurred during the period 1993-4 and is mainly predetermined.
} 
a vector of variables that can be expected to be correlated with current training but uncorrelated with the unobserved temporary shock. This vector includes all the explanatory variables in Table 3 drawn from the 1994 wave, with the exclusion of unemp5 and $u l$, that are drawn from the 1996 wave, plus training incidence in 1994 and a dummy indicating whether the individual was searching for a new job back in 1994. The identifying assumption is that, conditional on the inclusion of country specific dummies, marital status, days of absence, health conditions, assignment to private employment, hours worked, training and job search in 1994 and unemployment five years before the survey are correlated with current training but uncorrelated with the temporary shock to current earnings growth.

The presence of the temporary shock $\epsilon_{96 i}-\epsilon_{94 i}$ can also induce endogeneity in employment status in 1996 because of the effect this shock can have on turnover decisions. I follow again Blundell, Dearden and Meghir and deal with this problem by estimating the employment selection term $\lambda_{E}$ from an employment probit, where the dependent variable is employment in 1996, conditional on having been employed in 1994, and the explanatory variables, drawn from the 1994 survey, are the same used in the training probit ${ }^{14}$.

I start my analysis of the returns to training in Table 8, where I present the estimates of (6) without interactions (columns 1 and 2) as well as a more general model, that allows the coefficient of training incidence in 1994 and 1996 to vary across countries (columns 3 and 4). For the general model I report only the significant interactions. The table shows that: a) with the exception of Italy, previous training reduces current earnings growth, that occurs between 1994 and 1996, by 3.6\%; b) in most countries, current training raises current earnings growth substantially, by 17.8 percentage points. This increase is lowest in Denmark $(12.2 \%)$ and highest in France $(22.5 \%)$; c) while the selection term for employment is never significant, the selection term for current training is significant and negative. Therefore, there is evidence of a negative cor-

\footnotetext{
${ }^{14}$ See Arulampalam, Booth and Elias [1995] for an alternative approach that uses a bivariate probit.
} 
relation between the unobserved temporary shock that affects current earnings growth and current training, suggesting that training incidence increases when the European economies are hit by negative temporary shocks.

The sharp difference in the effect of previous and current training on current earnings growth points to the possibility that an important component of the private returns to training be temporary. According to this interpretation, participation to previous training increases earnings in 1994, but this increase partially disappears within two years, thereby generating negative earnings growth between 1994 and 1996.

Table 9 presents the results of the estimation of the full model in (6). I show two alternative versions of the same model: the full specification in columns (1) - (2), and a restricted specification in columns (3) and (4), that includes only the significant interaction terms between education, training and labor market experience. Focusing on the simplest specification, I find evidence of significant interactions between both previous and current training and educational attainment. Most of these interactions include labor market experience. Because of this, in Table 10 I show how current earnings growth varies with training when both educational attainment and labor market experience are allowed to vary.

Consider first previous training. At zero labor market experience $(X=0)$, the percentage change in hourly earnings associated to training is $-0.7 \%$, independently of educational attainment. For college graduates, however, this percentage falls as experience increases: at 20 years of experience, close to the sample average, the contribution of previous training to earnings growth is $-4.7 \%$. These findings confirm that the impact of previous training on current earnings growth is negative and add that this effect is larger in absolute value among more experienced individuals.

Next consider current training. At zero labor market experience, training increases current earnings growth by $12.8 \%$ among individuals with less than college education and by $21.6 \%$ among college graduates. For the latter group, the contribution of training to earnings growth falls with experience and is equal to $14 \%$ and to $10.4 \%$ at 10 and 20 years 
of experience respectively. I conclude that there is evidence in favor of the hypothesis that current training and education are complements in the production of human capital. This evidence, however, is limited to individuals with relatively short labor market experience ${ }^{15}$. Since more experienced individuals have completed college earlier than less experienced individuals with the same educational attainment, these findings suggest that recent college education increases the contribution of current training to earnings growth, but outdated college education reduces it.

The existing empirical research on the impact of training on current and future earnings usually finds that training matters. According to Lynch (1992), training affects significantly the earnings of young American workers ${ }^{16}$. Blanchflower and Lynch (1994) study the earnings of young Americans and find that employer provided training increase earnings by about $12 \%$. Arulampalam, Booth and Elias (1995) find that expected earnings of young Britons who have experienced at least one training event increase by more than $10 \%$. Positive effects of training on earnings are also found by Blundell, Dearden and Meghir (1994). Pischke (2000) examines German data and find that the returns to training are relatively low, at least compared to the US experience. In particular, employer provided training increases the earnings of training recipients by only 2 to 5 percent $^{17}$. Groot, Hartog and Oosterbeck (1994) study the Dutch case and estimate that employees who have participated at least once to employer provided training earn $11 \%$ more than other employees. Finally, Goux and Maurin (1998) use French data and show that the returns to training are close to zero.

This paper contributes to the literature with the following results: a) current training, both on the job and off the job, increases current earnings growth. Evaluated at the sample average labor market experience, the contribution of current training to earnings growth is $12.8 \%$ for individuals with at most upper secondary education and $11.7 \%$ for

\footnotetext{
${ }^{15}$ More precisely, complementarity holds for individuals with less than 14 years of labor market experience.

${ }^{16}$ See also Brown (1989) and Bishop (1994).

${ }^{17}$ See also Winkelmann (1994)
} 
college graduates; b) an important component of the observed increase in earnings growth associated to training is likely to be temporary, as suggested by the negative impact of previous training on current growth; c) for individuals with less than college education the private returns to current training do not vary with experience; for college workers, however, these returns decline substantially with labor market experience. If there is persistency in training, so that college educated individuals who have invested early on keep investing later in their working life, this result suggests that college graduates have decreasing marginal returns to training. One reason could be that as they age their education becomes increasingly outdated; e) there is evidence that the returns from current training, measured in terms of current earnings growth, are higher among the more educated who have relatively short labor market experience than among the less educated with the same experience in the labor market.

\section{Conclusions}

I have used the European Community Household Panel to study in a comparative perspective the interaction between training and educational attainment. I have identified three areas of interaction: 1) individual educational attainment and training incidence; 2) aggregate educational attainment as a positive external effect on training; 3) complementarity of education and training in the production of earnings capacity and human capital.

I have found that individuals with higher education are more likely to invest in training. The link between these two variables is much stronger in countries with a comprehensive school system (the UK or Ireland) than in countries with a stratified system (Germany), suggesting that training after school could be required to compensate for the relative lack of specialization provided by the former system. I have also found that the relationship between education and training is stronger for the older and educated birth cohorts, which points to the possibility that current training is a substitute for outdated education. 
There is evidence in support of the presence of a positive supply externality, because countries with higher educational attainment have a higher training incidence, even after controlling for individual educational attainment. Labor market institutions also matter for training incidence, which is higher in countries with higher union density, stronger employment protection and lower minimum wages (as a proportion of the average wage).

Finally, there is evidence that for college graduates the returns to current training decline with labor market experience. This suggests that for the more educated investment in training early in the working life is more productive than later investment, perhaps because education becomes increasingly obsolete with time. Overall, there is evidence in favor of the complementarity between education and current training in the production of human capital. This evidence, however, is limited to individuals with relatively short labor market experience. 


\section{References}

[1] Acemoglu, D., [2000], Technical Change, Inequality and the Labor Market, NBER Working paper no. 7800, Cambridge, MA.

[2] Acemoglu, D. and Pischke, J. [1998], Beyond Becker: Training in Imperfect Labor Markets, NBER Working Papers \# 6740

[3] Acemoglu, D. and Pischke, J. [1999], The structure of wages and investment in general training, Journal of Political Economy.

[4] Arulampalam, W., Booth, A. and Elias, P., [1995], Work related training and earnings growth for young men in Britain, mimeo, Warwick University.

[5] Bishop, J. [1994] The impact of previous training on productivity and wages, in Lynch, L. (ed.), Training and the Private Sector: International Comparisons, Chicago.

[6] Blanchflower, D. and Lynch, L. [1994], Training at work: a comparison of the US and British youths, in Lynch, L. (ed.), Training and the Private Sector: International Comparisons, Chicago.

[7] Blundell, R., Dearden, L. and Meghir, C. [1994], The determinants and effects of work related training in Britain, mimeo, University College London.

[8] Booth, A., Francesconi, M. and Zoega, G., [1999], Training, rent sharing and unions, mimeo, Essex University.

[9] Brown, J. [1989], Why do wages increase with tenure? On-thejob training and life-cycle wage growth observed within firms, The American Economic Review, 79, 971-991.

[10] Brunello, G. and Giannini, M. [2000], Stratified or comprehensive? The economic efficiency of school design, ISER Discussion Paper, Essex University, 2000-32

[11] Brunello, G. and Medio, A., [2001], An Explanation of international differences in education and workplace training, in The European Economic Review, 1, 307-22.

[12] Card, D. and Krueger, A., [1990], Does School Quality Matter? The Journal of Political Economy, 100, 1, 1-40.

[13] European Commission [1999], EHCP UDB Manual, Bruxelles.

[14] Goux, D. and Maurin, E., [1998], Returns to continuous training: 
evidence from French worker-firm matched data, mimeo.

[15] Groot, W, Hartog, J. and Oosterbeeck, H. [1994], Returns to withincompany schooling of employees: the Netherlands, in Lynch, L. (ed.), Training and the Private Sector: International Comparisons, Chicago.

[16] Hannah, F., Raffe, K. and J. Smyth, [1996], Cross-National research in school to work transition: an analytical framework, OECD, mimeo.

[17] Lassibille, G. and Navarro Gomez, M., [1998], Organization and efficiency of education systems: some empirical findings, LEO-CRESP wp-04, Univerity of Orleans.

[18] Lynch, L. (ed.), [1994] Training and the Private Sector: International Comparisons, Chicago.

[19] Lynch, L. [1992], Private sector training and the earnings of young workers, American Economic Review, 82, 299-312.

[20] Neuman, S., and Weiss, A., [1995], On the effects of schooling vintage on experience - earnings profiles: theory and evidence, The European Economic Review, 943-55.

[21] Nickell, S. and Layard, R., [1999], "Labour Market Institutions and Economic performance", Centre for Economic Performance Discussion Paper \#23, Oxford University.

[22] OECD [1995], Education at a Glance, Paris.

[23] OECD [1999], Employment Outlook, Paris.

[24] Pischke, J., [2000], Continuous training in Germany, NBER working paper \# $13 \%$.

[25] Rosen, S., [1976], A Theory of life earnings, Journal of Political Economy, S45-62.

[26] Shavit, Y. and Muller, W. [1998], From School to Work, Clarendon Press.

[27] Snower, D. [1994], The Low-Skill, Bad-Job Trap, Discussion Paper n.14, Birbeck College, London.

[28] Soskice, D. [1994], Reconciling Markets and Institutions: The German Apprenticeship System, in Lynch, L, Training and the Private Sector, University of Chicago Press. 
[29] Willis, R. [1986], Wage Determinants: A Survey and Reinterpretation of Human Capital Earnings Functions, in Ashenfelter, O. and Layard, R.(1986), Handbook of Labor Economics, volume 1, 525602.

[30] Winkelmann, R. [1994], Training, earnings and mobility in Germany, CEPR working paper \#982. 
Table 1. Training incidence. By educational attainment. By country and gender. 1996. Number of observations: 45444. M: males; F: females; Nobs: number of observations.

\begin{tabular}{l|cc|cc|cc|c}
\hline \hline & $T$ & $T$ & $E_{3}$ & $E_{3}$ & $E_{2}$ & $E_{2}$ & Nobs \\
\hline \hline & $M$ & $F$ & $M$ & $F$ & $M$ & $F$ & \\
Denmark & .491 & .522 & .369 & .424 & .416 & .375 & 3786 \\
Germany & .253 & .250 & .298 & .163 & .504 & .568 & 2495 \\
Netherlands & .110 & .142 & .238 & .231 & .572 & .543 & 4113 \\
Belgium & .203 & .178 & .363 & .505 & .352 & .290 & 2244 \\
France & .169 & .180 & .245 & .307 & .451 & .410 & 5013 \\
UK & .437 & .417 & .305 & .271 & .350 & .375 & 2939 \\
Ireland & .100 & .145 & .222 & .254 & .397 & .510 & 2365 \\
Italy & .076 & .118 & .097 & .121 & .402 & .496 & 5351 \\
Greece & .048 & .065 & .274 & .406 & .344 & .320 & 2562 \\
Spain & .139 & .202 & .247 & .378 & .193 & .236 & 4245 \\
Portugal & .025 & .032 & .046 & .098 & .117 & .171 & 3959 \\
Austria & .233 & .213 & .078 & .110 & .789 & .676 & 2954 \\
Finland & .515 & .565 & .274 & .452 & .544 & .362 & 3418 \\
\hline \hline
\end{tabular}


Table 2. Summary statistics of the variables in the training regression. 13 countries in 1996.

\begin{tabular}{lc|c}
\hline \hline & Mean & Stand. Dvt. \\
\hline T & .209 & .407 \\
Age & 38.228 & 10.363 \\
Exp & 19.450 & 11.393 \\
Married & .647 & .477 \\
Absence & 1.117 & 4.258 \\
Hours & 38.770 & 8.260 \\
Health & .974 & .158 \\
Unemp & .231 & .421 \\
Ulong & .080 & .272 \\
Gender & .568 & .495 \\
Private & .657 & .474 \\
\hline \hline
\end{tabular}


Table 3. Training Probits. With and without interactions with country dummies and with school design (tracking). Marginal effects.

\begin{tabular}{l|cc|cc|cc}
\hline \hline & Coef. & Std. Dvt. & Coef. & Std. Dvt. & Coef. & Std. Dvt. \\
\hline Gender & -.004 & .004 & -.004 & .004 & -.003 & .004 \\
$E_{3}$ & $.085^{* *}$ & .008 & $.087^{* *}$ & .008 & $.099^{* *}$ & .010 \\
$E_{2}$ & $.056^{* *}$ & .005 & $.048^{* *}$ & .009 & $.073^{* *}$ & .007 \\
$E_{3} *$ Track. & & & & & $-.011^{* *}$ & .005 \\
$E_{2} *$ Track. & & & & & $-.015^{* *}$ & .005 \\
$E_{3} * N L$ & & & $-.112^{* *}$ & .008 & & \\
$E_{3} *$ BE & & & $-.031^{* *}$ & .015 & & \\
$E_{3} * F R$ & & & $.067^{* *}$ & .020 & & \\
$E_{3} * I R$ & & & $.100^{* *}$ & .028 & & \\
$E_{2} * G E$ & & & $-.029^{* *}$ & .012 & & \\
$E_{2} *$ DK & & & $-.028^{*}$ & .013 & & \\
$E_{2} * N L$ & & & $-.075^{* *}$ & .013 & & \\
$E_{2} *$ UK & & & $.054^{* *}$ & .022 & & \\
$E_{2} * I R$ & & & $.057^{* *}$ & .022 & & \\
$E_{2} * S P$ & & & $.070^{* *}$ & .020 & & \\
$E_{2} *$ AU & & & $.042^{*}$ & .026 & & \\
$E_{2} *$ FI & & & $.044^{* *}$ & .003 & & \\
Age & $-.003^{* *}$ & .0006 & $-.003^{* *}$ & .0006 & $-.002^{* *}$ & .00006 \\
X & -.0002 & .0005 & .00001 & .0005 & -.0002 & .0005 \\
Married & $-.009^{* *}$ & .004 & $-.008^{*}$ & .004 & $-.009^{* *}$ & .004 \\
Absence & $-.001^{* *}$ & .0004 & $-.001^{* *}$ & .0004 & $-.001^{* *}$ & .0004 \\
Unemp5 & $-.041^{* *}$ & .005 & $-.041^{*}$ & .005 & $-.042^{* *}$ & .005 \\
Ulong & $-.026^{* *}$ & .008 & $-.025^{* *}$ & .009 & $-.025^{* *}$ & .0009 \\
Health & $.023^{*}$ & .012 & $.025^{*}$ & .013 & $.024^{*}$ & .012 \\
Private & $-.054^{* *}$ & .006 & $-.053^{* *}$ & .006 & $-.054^{* *}$ & .006 \\
Hours & $.002^{* *}$ & .0002 & $.002^{* *}$ & .0002 & $.002^{* *}$ & .0002 \\
\hline Nobs & 37756 & & 37756 & & 37756 & \\
$R^{2}$ & 0.22 & & 0.23 & & 0.23 & \\
\hline \hline
\end{tabular}

${ }^{*}$ significant at the $10 \%$ level of confidence; ${ }^{* *}$ significant at the $5 \%$ level of confidence. Robust standard errors. Each regression includes a constant, country, occupation and sector specific dummies. NL: Netherlands; BE: Belgium; FR: France; IR: Ireland; GE: Germany; DK: Denmark; SP: Spain; AU: Austria; FI: Finland; UK: United Kingdom. 
Table 4. Training Duration. Ordered Probit.

\begin{tabular}{lcc}
\hline \hline & Coef. & Std. Dvt. \\
\hline Gender & $-.089^{* *}$ & .036 \\
$E_{3}$ & -.051 & .052 \\
$E_{2}$ & -.050 & .044 \\
Age & $-.022^{* *}$ & .005 \\
$X$ & .004 & .004 \\
Married & $-.236^{* *}$ & .033 \\
Absence & -.002 & .003 \\
Unemp5 & $.160^{* *}$ & .044 \\
Ulong & .055 & .076 \\
Health & .109 & .121 \\
Private & $.147^{* *}$ & .045 \\
Hours & $-.008^{* *}$ & .002 \\
\hline Nobs & 37756 & \\
$R^{2}$ & 0.144 & \\
\hline \hline
\end{tabular}

Notes: see Table 3. 
Table 5. Training Probit. With cohort effects.

\begin{tabular}{lcc}
\hline \hline & Coef. & Std. Dvt. \\
\hline Gender & -.004 & .004 \\
$E_{3}$ & $.052^{* *}$ & .014 \\
$E_{2}$ & $.033^{* *}$ & .017 \\
$E_{3} * C 3039$ & .018 & .016 \\
$E_{3} * C 4049$ & $.034^{* *}$ & .017 \\
$E_{3 *} C 50$ & $.056^{* *}$ & .021 \\
$E_{2} * C 3039$ & .016 & .014 \\
$E_{2} * C 4049$ & $.027^{*}$ & .014 \\
$E_{2} * C 50$ & $.051^{* *}$ & .018 \\
$C 3039$ & $-.022^{*}$ & .011 \\
$C 4049$ & $-.037^{* *}$ & .013 \\
C50 & $-.068^{* *}$ & .014 \\
$X$ & $-.001^{* *}$ & .0004 \\
Married & $-.011^{* *}$ & .004 \\
Absence & $-.001^{* *}$ & .0004 \\
Unemp5 & $-.040^{* *}$ & .005 \\
Ulong & $-.028^{* *}$ & .009 \\
Health & $.024^{*}$ & .013 \\
Private & -.054 & .006 \\
Hours & .002 & .0002 \\
\hline Nobs & 37756 & \\
$R^{2}$ & 0.225 & \\
\hline \hline
\end{tabular}

Notes: see Table 3. 
Table 6. Labor market and education institutions. By country.

\begin{tabular}{lccccc}
\hline \hline & Epl & Udens & Kaitz & Track. & Ed92 \\
\hline \hline Germany & 12 & .33 & .55 & 3 & .82 \\
Denmark & 3.25 & .73 & .54 & 0 & .59 \\
Netherlands & 7.25 & .28 & .55 & 2 & .58 \\
Belgium & 10.5 & .53 & .60 & 2 & .45 \\
France & 9.5 & .14 & .50 & 1 & .52 \\
UK & 2.25 & .43 & .40 & 0 & .68 \\
Ireland & 2.75 & .53 & .55 & 0 & .42 \\
Italy & 14.25 & .28 & .71 & 1 & .28 \\
Spain & 11.5 & .14 & .32 & 1 & .23 \\
Portugal & 12.5 & .44 & .45 & 1 & .14 \\
Austria & 9 & .47 & .62 & 3 & .68 \\
Finland & 10.5 & .71 & .52 & 0 & .61 \\
\hline \hline
\end{tabular}

Notes: OECD [1999], Nickell and Layard [1999] 
Table 7. Training probit. With country - specific variables.

\begin{tabular}{lcc}
\hline \hline & Coef. & Std. Dvt. \\
\hline Kaitz index & $-.454^{* *}$ & .218 \\
Udens & $.247^{* *}$ & .104 \\
Epl & $.012^{* *}$ & .005 \\
Tracking & $-.077^{* *}$ & .017 \\
Ed92 & $.574^{* *}$ & .086 \\
Gender & .001 & .007 \\
$E_{3}$ & $.112^{* *}$ & .022 \\
$E_{2}$ & $.072^{* *}$ & .018 \\
Age & $-.003^{*}$ & .001 \\
$X$ & -.0004 & .001 \\
Married & $-.012^{* *}$ & .006 \\
Absence & $-.002^{*}$ & .001 \\
Unemp5 & $-.035^{* *}$ & .011 \\
Ulong & -.021 & .022 \\
Health & $.031^{*}$ & .017 \\
Private & $-.058^{* *}$ & .023 \\
Hours & $.002^{* *}$ & .0005 \\
\hline Nobs & 35439 & \\
$\mathrm{R}^{2}$ & 0.20 & \\
\hline \hline
\end{tabular}

Note: see Table 3. The regression includes a constant, occupation and sectorial dummies. 
Table 8. Training and earnings growth.

\begin{tabular}{lcccc}
\hline \hline & $(1)$ & $(2)$ & $(3)$ & $(4)$ \\
\hline \hline & Coef. & St.Dvt. & Coef. & St.Dvt. \\
\hline Gender & $.076^{* *}$ & .007 & $.075^{* *}$ & .007 \\
$E_{3}$ & $.151^{* *}$ & .010 & $.147^{* *}$ & .010 \\
$E_{2}$ & $.050^{* *}$ & .007 & $.047^{* *}$ & .007 \\
$X$ & $.003^{* *}$ & .0009 & $.003^{* *}$ & .0009 \\
$X^{2}$ & $-.00005^{* *}$ & .00002 & $-.00005^{* *}$ & .00002 \\
$T_{94}$ & $-.020^{* *}$ & .009 & $-.036^{* *}$ & .011 \\
$T_{96}$ & $.125^{* *}$ & .039 & $.178^{* *}$ & .041 \\
$T_{94} * I T$ & - & - & $.055^{* *}$ & .018 \\
$T_{96} * D K$ & - & - & $-.056^{* *}$ & .013 \\
$T_{96} * F R$ & - & - & $.047^{* *}$ & .023 \\
$\lambda_{E}$ & .006 & .013 & .007 & .013 \\
$\lambda_{T 96}$ & $-.053^{* *}$ & .022 & $-.081^{* *}$ & .023 \\
\hline Nobs & 21734 & & 21734 & \\
$\mathrm{R}^{2}$ & .079 & & .081 & \\
\hline \hline
\end{tabular}

Notes: see Table 3. IT: Italy. 
Table 9. Training and earnings growth, including interactions between education and training.

\begin{tabular}{|c|c|c|c|c|}
\hline & $(1)$ & & $(2)$ & \\
\hline & Coef. & St.Dvt. & Coef. & 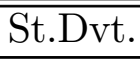 \\
\hline Gender & $.068^{* *}$ & .007 & $.068^{* *}$ & .007 \\
\hline$E_{3}$ & .014 & .026 & .019 & .025 \\
\hline$E_{2}$ & -.027 & .021 & -.020 & .020 \\
\hline$X$ & $-.003^{*}$ & .001 & $-.002^{*}$ & .001 \\
\hline$X^{2}$ & .00005 & .00003 & .00005 & .00003 \\
\hline$T_{94}$ & .046 & .057 & -.007 & .010 \\
\hline$T_{96}$ & .056 & .067 & $.128^{* *}$ & .042 \\
\hline$X * T_{94}$ & -.005 & .005 & - & - \\
\hline$X * T_{96}$ & .008 & .006 & - & - \\
\hline$X^{2} * T_{94}$ & .0001 & .0001 & - & - \\
\hline$X^{2} * T_{96}$ & -.0001 & .0001 & - & - \\
\hline$E_{3} * T_{94}$ & -.035 & .068 & - & - \\
\hline$E_{2} * T_{94}$ & -.083 & .065 & - & - \\
\hline$E_{3} * T_{96}$ & $.177^{* *}$ & .070 & $.088^{* *}$ & .034 \\
\hline$E_{2} * T_{96}$ & $.154^{* *}$ & .075 & - & - \\
\hline$X * E_{3}$ & $.012^{* *}$ & .002 & $.012^{* *}$ & .002 \\
\hline$X * E_{2}$ & $.007^{* *}$ & .002 & $.006^{* *}$ & .001 \\
\hline$X^{2} * E_{3}$ & $-.0002^{* *}$ & .00006 & $-.0002^{* *}$ & .00005 \\
\hline$X^{2} * E_{2}$ & $-.0001^{* *}$ & .00005 & $-.0001^{* *}$ & .00004 \\
\hline$X * E_{3} * T_{94}$ & .003 & .006 & $-.002^{* *}$ & .0006 \\
\hline$X * E_{2} * T_{94}$ & .008 & .006 & - & - \\
\hline$X^{2} * E_{3} * T_{94}$ & -.0001 & .0001 & - & - \\
\hline$X^{2} * E_{2} * T_{94}$ & -.0001 & .0001 & - & - \\
\hline$X * E_{3} * T_{96}$ & $-.018^{* *}$ & .007 & $-.009^{* *}$ & .003 \\
\hline$X * E_{2} * T_{96}$ & $-.015^{*}$ & .007 & $.0002^{* *}$ & .00009 \\
\hline$X^{2} * E_{3} * T_{96}$ & $.0003^{* *}$ & .0001 & - & - \\
\hline$X^{2} * E_{2} * T_{96}$ & $.0003^{*}$ & .0001 & - & - \\
\hline$\lambda_{E}$ & -.011 & .014 & -.011 & .014 \\
\hline$\lambda_{T 96}$ & $-.066^{* *}$ & .024 & $-.055^{* *}$ & .023 \\
\hline Nobs & 21734 & & 21734 & \\
\hline $\mathrm{R}^{2}$ & .0826 & & .0821 & \\
\hline
\end{tabular}

Note: see Table 3. 
Table 10. Earnings growth due to participation to training. By educational attainment.

\begin{tabular}{lccc}
\hline \hline & $E_{1}$ & $E_{2}$ & $E_{3}$ \\
\hline \hline$T_{94}$ & & & \\
$X=0$ & -.007 & -.007 & -.007 \\
$X=10$ & -.007 & -.007 & -.027 \\
$X=20$ & -.007 & -.007 & -.047 \\
\hline$T_{96}$ & & & \\
\hline$X=0$ & .128 & .128 & .216 \\
$X=10$ & .128 & .128 & .140 \\
$X=20$ & .128 & .128 & .104 \\
\hline \hline
\end{tabular}




\section{IZA Discussion Papers}

\section{No Author(s)}

231

G. Saint-Paul

232

E. Bardasi

M. Francesconi

233

C. Dustmann

C. M. Schmidt

234 R. Rotte

M. Steininger

235 W. Schnedler

236 R. Hujer

M. Caliendo

237 S. Klasen

I. Woolard

238 R. Euwals

A. Börsch-Supan

A. Eymann

239 F. Andersson

K. A. Konrad

240

W. Koeniger

241

W. Koeniger

242
G. Faggio
J. Konings

243

E. Brainerd

244

S. M. Fuess, Jr. M. Millea
Titel

Area

Date

The Economics of Human Cloning

5

$12 / 00$

The Effect of Non-Standard Employment on

5

$12 / 00$

Mental Health in Britain

The Wage Performance of Immigrant Women:

Full-Time Jobs, Part-Time Jobs, and the Role of

Selection

Sozioökonomische Determinanten extremistischer 3

$12 / 00$

Wahlerfolge in Deutschland: Das Beispiel der Europawahlen 1994 und 1999

Who gets the Reward? An Empirical Exploration

of Bonus Pay and Task Characteristics

Evaluation of Active Labour Market Policy:

6

$12 / 00$

Methodological Concepts and Empirical

Estimates

Surviving Unemployment without State Support:

3

$12 / 00$

South Africa

The Saving Behaviour of Two Person House-

5

$12 / 00$

holds: Evidence from Dutch Panel Data

Human Capital Investment and Globalization in

5

01/01

Extortionary States

Labor and Financial Market Interactions: The the UK 1969-95

Trade, Labor Market Rigidities, and GovernmentFinanced Technological Change

$01 / 01$

Job Creation, Job Destruction and Employment

4

$01 / 01$

Growth in Transition Countries in the 90's

Economic Reform and Mortality in the Former

4

$01 / 01$ Soviet Union: A Study of the Suicide Epidemic in the 1990s

Pay and Productivity in a Corporatist Economy: Evidence from Austria 
The Optimal Level and Composition of Retirement Benefit Systems

250 T. J. Hatton

J. G. Williamson

Demographic and Economic Pressure on

Emigration out of Africa

01/01

251 R. Yemtsov

Labor Markets, Inequality and Poverty in Georgia

$01 / 01$

252 R. Yemtsov

Inequality and Income Distribution in Georgia

$01 / 01$

253 R. Yemtsov

Living Standards and Economic Vulnerability in Turkey between 1987 and 1994 
263 N. Datta Gupta

N. Smith

264

C. Dustmann

265

M. Rosholm

M. Svarer

266 C. Dustmann

O. Kirchkamp

267 A. Newell

268

A. Newell

B. Reilly

269

H. Buddelmeyer

270

B. Augurzky

C. M. Schmidt

271 B. Augurzky

C. M. Schmidt

272 C. Belzil

J. Hansen

273 G. Saint-Paul

274

P. J. Pedersen

N. Smith

275 G. S. Epstein

T. Lecker

276

B. Amable

D. Gatti
Children and Career Interruptions:

The Family Gap in Denmark

5

$02 / 01$

Return Migration, Wage Differentials, and the 1

$02 / 01$

Optimal Migration Duration

Structurally Dependent Competing Risks

$02 / 01$

The Optimal Migration Duration and Activity

$02 / 01$

Choice after Re-migration

The Distribution of Wages in Transition Countries

4

$03 / 01$

The Gender Pay Gap in the Transition from

4

03/01

Communism: Some Empirical Evidence

Re-employment Dynamics of Disabled Workers

3

03/01

The Evaluation of Community-Based

6

$03 / 01$

Interventions: A Monte Carlo Study

The Propensity Score: A Means to An End

6

03/01

Heterogeneous Returns to Human Capital and

5

03/01

Dynamic Self-Selection

Distribution and Growth in an Economy with

5

$03 / 01$ Limited Needs

Unemployment Traps: Do Financial Dis-

3

$03 / 01$

incentives Matter?

Multi-Generation Model of Immigrant Earnings

03/01

Theory and Application

The Impact of Product Market Competition on

5

03/01 Employment and Wages 

national Integration

klund

S. Vroman

283 M. Hagedorn
A. Kaul

V. Reinthaler

Welfare Analysis in a Schumpeterian Growth to Internal Promotion for Young U.S. Men and Women Living Arrangements 

and the Rising Returns to Skill: US and France 1964-2000

293 D. Cobb-Clark T. F. Crossley

294 Š. Jurajda

N. Smith

L. Husted

297 J. C. van Ours J. Veenman

P. Cahuc

E. Wasmer
Gender, Comparative Advantage and Labor Market Activity in Immigrant Families Insurance Compensation on the Labor Market Histories of Displaced Workers

Individual Pay and Outside Options:

Intergenerational Transmissions and the Schoolto-Work transition of $2^{\text {nd }}$ Generation Immigrants

The Educational Attainment of Second Generation 1 Immigrants in The Netherlands

Returns to Education and Wage Equations and Subjective Well-Being The Role of Social Work

Economic and Social Perspectives of Immigrant 06/01 Children in Germany 
G. Abío

E. Berenguer

Accounting Perspective on Fiscal Policy and

C. Patxot 